May 2014

\title{
Preparing LIS Students for a Career in Metadata Librarianship
}

Brighid Mooney Gonzales

San Jose State University, brighidmooney@yahoo.com

Follow this and additional works at: https://scholarworks.sjsu.edu/ischoolsrj

Part of the Library and Information Science Commons

\section{Recommended Citation}

Mooney Gonzales, B. (2014). Preparing LIS Students for a Career in Metadata Librarianship. School of Information Student Research Journal, 4(1). https://doi.org/10.31979/2575-2499.040103 Retrieved from https://scholarworks.sjsu.edu/ischoolsrj/vol4/iss1/3

This article is brought to you by the open access Journals at SJSU ScholarWorks. It has been accepted for inclusion in School of Information Student Research Journal by an authorized administrator of SJSU ScholarWorks. For more information, please contact scholarworks@sjsu.edu. 


\title{
Preparing LIS Students for a Career in Metadata Librarianship
}

\begin{abstract}
This study examines the field of metadata librarianship and its emergence from the field of traditional MARC cataloging. Through a survey distributed to academic librarians, public librarians, digital librarians, special librarians, corporate librarians, archivists and others currently working with metadata, data was collected to determine what Library and Information Science students interested in metadata librarianship need to know to pursue a career in this field. The data collected includes job titles encompassing metadata work, the typical career trajectories of those working in the field, education and training received both prior to and after entering the metadata field, and the most frequently used metadata standards in modern library and information science environments. The results of the study revealed the LIS courses metadata specialists have found most useful to their current work, which standards are most frequently being used and areas where LIS programs could improve current course offerings to provide adequate preparation for LIS students interested in this area.
\end{abstract}

\section{Keywords}

metadata, library science students, education, training, library science curriculum 
Preparing LIS Students for a Career in Metadata Librarianship

While librarianship has historically been affected by advances in technology, the job titles of librarians have long reflected traditional areas of work such as reference and instruction, administration, cataloging, collections, circulation, youth services, and archives. Since the turn of the century, some of these technological changes have ushered in a shift from traditional library job titles to emerging job titles, such as virtual services librarian, digital librarian, electronic resources librarian, and metadata librarian. The shift from cataloging librarian to metadata librarian is one that has been especially gradual and complicated, since metadata can also encompass the work of traditional catalogers, including the description of printed texts, serials and multimedia resources, as well as the description and organization of digital materials (Veve and Feltner-Reichert, 2010).

Library science programs often now offer courses in metadata and other technology-focused subjects. However, the link between traditional cataloging and metadata work can be confusing for Library and Information Science (LIS) students interested in pursuing a career path in this emerging area. This study seeks to better inform the educational choices of LIS students interested in this field by answering questions about what library school courses and metadata standards they need to know to pursue a career in metadata librarianship. Among the data collected is information about the types and variety of job titles that can encompass metadata work, the type of libraries most likely to employ metadata specialists, common career trajectories for those working in metadata, training and education received before and after taking their current position, the most useful coursework to prepare for a career in metadata, and the metadata standards most commonly being used in library and information environments today. While the job duties involved in both cataloging and metadata work can overlap, students interested in metadata will be best prepared for work in the field if they have a strong foundation in traditional cataloging and the related standards, including practical hands-on experience, and a broad exposure to topics in metadata and technology.

\section{LITERATURE REVIEW}

In NISO's booklet Understanding Metadata (2004), the group defines metadata as "structured information that describes, explains, locates, or otherwise makes it easier to retrieve, use, or manage an information resource" (p. 1). As such, traditional library cataloging using MARC21and AACR2 is a form of metadata, though "metadata" also describes schemes "developed to describe various types of textual and non-textual objects including published books, electronic 
documents, archival finding aids, art objects, educational and training materials, and scientific datasets" (p. 1). While NISO defines cataloging as a form of metadata, "cataloging" can also refer explicitly to the description of print materials and "metadata" to the description of electronic or non-print materials.

As these types of materials have proliferated, so has the need for cataloging professionals to know and be able to use non-MARC metadata standards (Veve and Feltner-Reichert, 2010). Also increasing is the trend toward creating professional metadata librarian positions separate from traditional cataloging positions. The appearance of metadata-specific job titles in professional job listings has continued to increase in recent years, though the distinction from cataloging is not always clear. A number of positions incorporate cataloging and metadata into a single job title, or combine metadata work with other digitally-related responsibilities.

Cataloging and metadata positions include a great diversity in job titles. In a document outlining emerging career trends for information professionals, San Jose State University (2013) also found a wide variety of job titles representing the metadata and taxonomy fields. Some of the job titles they found in this area include "Resource Description Librarian," "Head of Metadata and Collections," and "Taxonomy Development Consultant." Park and Lu (2009) found that the titles of "Metadata Librarian" and "Catalog/Cataloging Librarian" appear most frequently throughout job listings, while slightly more than half of job titles contain the terms catalog, cataloger or cataloging. Park and Lu (2009) also found an increase in job titles relating to electronic resources as electronic periodicals increasingly replace print journals. Han and Hswe (2009) suggest that the emergence of metadata librarian job listings "reflects the changing role of cataloging librarians as well as a shift in library resources and technology" (p. 129).

Another trend is library delegation of cataloging responsibilities to paraprofessionals and other support staff, leaving professional catalogers to take on additional duties. Some of the non-cataloging duties now frequently required of cataloging librarians include "management, supervisory, leadership and policy related responsibilities" (Glasser, 2007, p. 44). Sometimes these professionals remain classified as cataloging librarians, while other times they take on new or combined titles, such as metadata librarian, or cataloging and metadata librarian respectively.

In spite of merging job titles and responsibilities in cataloging and metadata positions today, there can still be some distinction made between the two. Han and Hswe (2009) suggest that the role of metadata librarian has evolved out of the cataloging librarian position. However, it has only been in the last 5 to 10 years that the number of metadata librarian positions posted has seen a significant increase. At the same time, the number of cataloging librarian 
positions has decreased (Han and Hswe, 2009). Han and Hswe (2009) claim the main distinction between cataloging and metadata positions is in the need for increased technology knowledge. While catalogers are often required to have knowledge of a foreign language, metadata librarians are "required to know a variety of metadata standards and have a facility for the IT [information technology] used for metadata sharing" (p. 135).

Calhoun (2007) suggests that there is an increasing need for metadata librarians to undertake the "organization of unstructured data," for which ease of access depends on their ability to develop and use "new automated tools for organizing, classifying, and discovering a very large volume of unstructured but useful data" (p. 180). Park and Lu (2009) report that the core areas of knowledge required for metadata librarians include "Electronic Resources Management (64.5\%), Awareness of Trends (55.1\%), and Digital Library Development $(48.6 \%) "$ (p. 152), but also note that general cataloging is still considered a primary responsibility for metadata professionals.

Throughout the literature, a variety of other skills, in addition to traditional cataloging skills, are cited as important for those in the metadata field. Some of these include "computer skills, oral and written communication skills, teaching skills, and knowledge of non-MARC metadata standards" (Glasser, 2007, p. 45). Metadata specialists may also find it necessary to maintain a "knowledge and familiarity with the new developments in the field" as well as writing technical documents, giving presentations, and working closely with "system administrators, interface designers, Web masters, and other technology-intensive positions" (Chapman, 2007, p. 281-282). Metadata professionals are often also required to take on "management activities such as administration, coordination, overseeing, supervision, policymaking, and strategic planning" (Park and Lu, 2009, p. 154). Calhoun (2007) writes that the future of libraries is in access systems and that "just as catalogers played the central role in creating nineteenthand twentieth-century tools -- the card and online catalogs -- metadata specialists will be needed to help build these new kinds of access systems" (p. 183).

Metadata librarians are also expected to have familiarity with and be able to use a variety of non-MARC metadata standards in addition to MARC and AACR2. Han and Hswe (2009) found that Dublin Core was one of the most frequently cited non-MARC standards required for metadata librarians, while Park and Lu (2009) named Dublin Core, EAD, MODS, TEI and VRA Core as the most important. Hsieh-Yee (2003) listed Dublin Core, AACR and metadata crosswalks as the top standards needed by metadata experts, while Hall-Ellis (2006) found employers frequently identified EAD, TEI and metadata for web pages as the most needed. Veve and Feltner-Reichert (2010) also found Dublin Core to be the non-MARC schema most often used by catalogers, though they reported many others, including local and customized schemas, were also in use. 
While the skills and knowledge cited as necessary varies widely throughout the literature, the common themes are technology and knowledge of current and emerging standards. Also appearing frequently in the literature is the need for LIS graduate programs to catch up to evolving demands for skilled metadata specialists and better prepare students for the work they will face upon entering the field. Hall-Ellis (2009) found that a significant number of employers "preferred that applicants had passed at least one cataloging and classification course" (p. 42); however, in some programs students are not given the opportunity to take much beyond an introductory cataloging course. Dulock (2011) interviewed new catalogers and found that the library science programs attended by interviewees offered an average of three cataloging courses. Dulock also found that $88 \%$ of the sample schools attended by interviewees required at least one cataloging course for graduation.

Fifty percent of interviewees in Dulock's study indicated they would have liked to have taken additional cataloging courses, or more advanced cataloging coursework, in order to be better prepared for their positions. Dulock also found that students who did not participate in a cataloging practicum felt less prepared for their professional cataloging positions than students who did. In a case study on teaching RDA to LIS students, Veitch, Greenberg, Keizer and Gunther (2013) found that "significant hands-on experience with real RDA records" (p. 356), in addition to a theoretical background (both of which were provided by their RDA Boot Camp), resulted in the most successful learning experience, further suggesting the need for practical experience in cataloging and metadata endeavors.

Hall-Ellis (2006) asserted that "metadata courses need to become regular offerings for graduate students who specialize in cataloging. Without the availability of courses that focus on metadata schemes, LIS graduates will enter the community of practitioners unprepared to work as catalog librarians" (p. 48). Hsieh-Yee (2003) also found that cataloging education had been greatly reduced, replaced by a "pattern of providing general coverage of cataloging in a required introductory course" (p. 13) instead of a detailed practical cataloging course.

Glasser (2007) suggests that students interested in pursuing cataloging attend conferences, join local and national library organizations, attain part-time work or an internship in a cataloging department, or seek out an independent study in cataloging. Park, Tosaka, Maszaros and Lu (2010) also found that the majority of metadata specialists in their study were interested in pursuing professional development opportunities, primarily through attending workshops and conferences. Respondents also expressed a strong need for more development opportunities in the study of markup languages and in the cataloging of non-print materials. 
The consensus across the literature is that rather than decreasing cataloging course offerings, schools should increase course offerings for in-depth cataloging concepts as well as specialized metadata concepts. In addition to taking multiple cataloging or metadata courses, students are advised to pursue practical experience in the form of internships or practicums to supplement their classroom education with hands-on experience.

\section{METHODOLOGY}

This study was conducted to collect information beneficial to LIS students interested in a career in the field of metadata, including relevant information on the most helpful coursework to take in school and metadata standards that are currently in use. Data was collected by means of a short questionnaire (see Appendix A) which was posted online and disseminated through a number of online channels, including Metadata Librarians Listserv, DC-General Listserv, Collib and AutoCAT. The survey link was sent out with a brief description of the type of questions being asked and the purpose of the study, with a request for those currently working with metadata in a professional capacity to follow the link to complete the survey anonymously.

Data was collected from those voluntarily electing to complete the survey with a total of 97 responses. Of the ten questions asked, respondents were only required to answer the first, and as such the remaining questions have differing numbers of responses which are accounted for in the findings section. For questions which allowed respondents to write in an open answer, responses were categorized according to similarities and counted together to reach the totals listed. Although the sample size of the survey is relatively small and nonexhaustive, and so cannot be generalized to the entire metadata field, the results show several broad trends which can provide useful guidance for current LIS students interested in this area.

\section{FINDINGS}

The survey data showed a wide variety in the job titles of those working with metadata in a professional capacity. The most common job titles were metadata specific titles such as "Metadata Librarian" or "Metadata Specialist," with 30.93\% of the 97 respondents falling into this category. Also common were job titles featuring a combination of metadata and cataloging, such as "Cataloging and Metadata Librarian" or "Monographic Cataloger and Metadata Specialist," representing $17.50 \%$ of respondents. Those consisting only of cataloging and/or technical services titles such as "Catalog Librarian," "Acquisitions and Cataloging Librarian" and "Head of Technical Services," represented $19.59 \%$ of respondents.

The remainder of respondent's job titles were scattered across various 
categories, such as those with non-specialized librarian titles ("Assistant Librarian") at just over five percent; job titles which combined digital services and metadata ("Metadata and Digital Initiatives Librarian") at just over six percent; job titles consisting only of digital ("Digital Projects Librarian") at just over four percent; and those in archives ("Digital Archivist," "Archivist for Metadata and Encoding") at just over five percent. A full $11.34 \%$ of respondents had job titles falling into the "other" category, or those not easily fitting into any of the other categories. These included job titles such as "Information Architect," "Assistant Professor," and "Education Assistant." Table 1 shows the percentage and number of respondents broken out by category of job title.

\begin{tabular}{|l|l|l|}
\hline Job Title & Number & Percentage \\
\hline Metadata-Specific Title & 30 & $30.93 \%$ \\
\hline Cataloging Only/Technical Services & 19 & $19.59 \%$ \\
\hline Metadata and Cataloging Combined & 17 & $17.50 \%$ \\
\hline Other & 11 & $11.34 \%$ \\
\hline Metadata and Digital Combined & 6 & $6.19 \%$ \\
\hline Non-Specialized Librarian Title & 5 & $5.15 \%$ \\
\hline Archives & 5 & $5.15 \%$ \\
\hline Digital Only & 4 & $4.12 \%$ \\
\hline Total & $\mathbf{9 7}$ & $\mathbf{1 0 0 \%}$ \\
\hline
\end{tabular}

Table 1: Breakdown of job titles reported by survey-takers by number and percentage of respondents.

In answering the question of what percentage of their job involves working directly with metadata, $15.63 \%$ of the 96 respondents who answered this question stated that $100 \%$ of their time was devoted to metadata work, while $17.71 \%$ spent less than $50 \%$ of their time working with metadata. The remaining respondents, or $66.67 \%$, indicated that they spent more than $50 \%$ but less than $100 \%$ of their time on metadata work.

The vast majority of the 96 respondents who answered the question related to their place of employment were employed at an academic library (77.08\%), while over nine percent worked in either public libraries, digital libraries, special libraries or corporate/business libraries. Thirteen respondents (13.54\%) indicated that they worked in "other" environments such as government, non-profit, or museums.

Respondents also reported using a wide variety of metadata standards in their work. Ninety-four respondents answered the question asking what standards 
they currently use in their work and the vast majority listed two or more standards each. The most common of these were traditional cataloging standards such as MARC and AACR2, as well as the newly developed RDA, which is slowly replacing these. These traditional cataloging standards together were listed a total of 60 times. The second most frequently listed standard was Dublin Core, appearing 56 times. While 29 different metadata standards were listed as being commonly used by the respondents, 12 of these only appeared one time each in the final list. The 12 most frequently mentioned standards listed by those responding appear in Table 2.

\begin{tabular}{|l|l|}
\hline Metadata Standards & $\begin{array}{l}\text { Times } \\
\text { Mentioned }\end{array}$ \\
\hline MARC/AACR2/RDA & 60 \\
\hline Dublin Core & 56 \\
\hline MODS & 19 \\
\hline XML & 13 \\
\hline VRA Core & 12 \\
\hline METS & 9 \\
\hline EAD & 5 \\
\hline DACS & 5 \\
\hline PREMIS & 5 \\
\hline Custom/Local Schemas & 4 \\
\hline RDF & 4 \\
\hline TEI & 4 \\
\hline
\end{tabular}

Table 2: Most frequently used metadata standards as reported by respondents

The job titles held by respondents before assuming their current position are equally as varied, although the majority of the 85 respondents who answered this question came into the metadata field from a cataloging or technical services position. A total of $35.96 \%$ fell into this category, with previous job titles such as "Cataloging Librarian," "Bibliographic Services," or "Electronic Services." A large percentage of respondents also named previous job titles which fell into the "other" category such as "Project Manager," "Consultant," and "Analyst," accounting for $17.98 \%$ of respondents. Those who came into their current position from a previous metadata position, with titles such as "Metadata Librarian" or "Metadata Specialist," represented $12.36 \%$ of respondents; while a slightly higher 
percentage (13.48\%) reported that they were either a student or an intern before taking their current position. The remainder were scattered across various categories such as digital ("Digital Materials Librarian") at almost nine percent, a combination of metadata and cataloging ("Cataloging and Metadata Projects Librarian") and non-specialized library titles ("Library Assistant") at just over three percent each, and reference/public services ("Reference Assistant") and archives ("Project Archivist") at just over two percent each. Table 3 shows the job areas in which respondents were employed before taking their current position, broken out by percentage.

\begin{tabular}{|l|l|l|}
\hline Previous Position & Times Mentioned & Percentage \\
\hline Technical Services or Cataloging & 32 & $35.96 \%$ \\
\hline Other & 16 & $17.98 \%$ \\
\hline Intern/Student & 12 & $13.48 \%$ \\
\hline Metadata-Specific Job Title & 11 & $12.36 \%$ \\
\hline Digital & 8 & $8.99 \%$ \\
\hline Metadata and Cataloging Combined & 3 & $3.37 \%$ \\
\hline Non-specific Library Position & 3 & $3.37 \%$ \\
\hline Archives & 2 & $2.25 \%$ \\
\hline Reference/Public Services & 2 & $2.25 \%$ \\
\hline Total & $\mathbf{8 9}$ & $\mathbf{1 0 0 \%}$ \\
\hline
\end{tabular}

Table 3: Previous job titles of current metadata librarians as reported by respondents.

Ninety-three participants answered the question asking what kind of experience they had working with metadata before taking their current position. Each respondent was able to select as many options as applied to them, accounting for the total of over $100 \%$. The majority of respondents had experience working with metadata from a previous job (75.27\%), while a large percentage also gained experience from school coursework (64.52\%). Another $38.71 \%$ indicated they had gained experience through internships and $36.56 \%$ gained experience through professional development outside of library school.

Nearly $80 \%$ of a total of 96 respondents indicated that they received metadata training by their employer after accepting their current position. While $21.88 \%$ indicated that they received no additional training after starting their 
current position, the remainder received additional training in metadata through professional development courses, workshops, employer-sponsored training or on-the-job training.

Many respondents also received metadata-specific education while they were in library school. Forty-seven out of the 94 respondents answering this question indicated that they took a metadata-specific course in library school, while another 29 indicated that they had taken a course that covered metadata within a broader subject area. Many respondents who commented on this question wrote that they had taken only a cataloging course ("When I was in Library school it was called Cataloging."), or that they attended library school before metadata courses were offered ("When I went to library school 22 years ago, there were no such classes").

Respondents were also asked to list the courses they took in library school that they find most helpful in their current position. The 86 respondents answering this question listed 37 different courses as being the most useful to their current work, though over half of these (19) were listed only one time each. After taking into account courses from different schools that may cover the same subject under slightly different names, the most frequently appearing courses are aggregated in the graph in Table 4 . The most useful course by far was cataloging which was named by respondents a total of 45 times. Metadata also appeared frequently, named by respondents 25 times. The other courses named most frequently include organization of information, advanced cataloging, digital libraries/digital collections, XML, indexing, database design/management, programming, management/administration and archives.

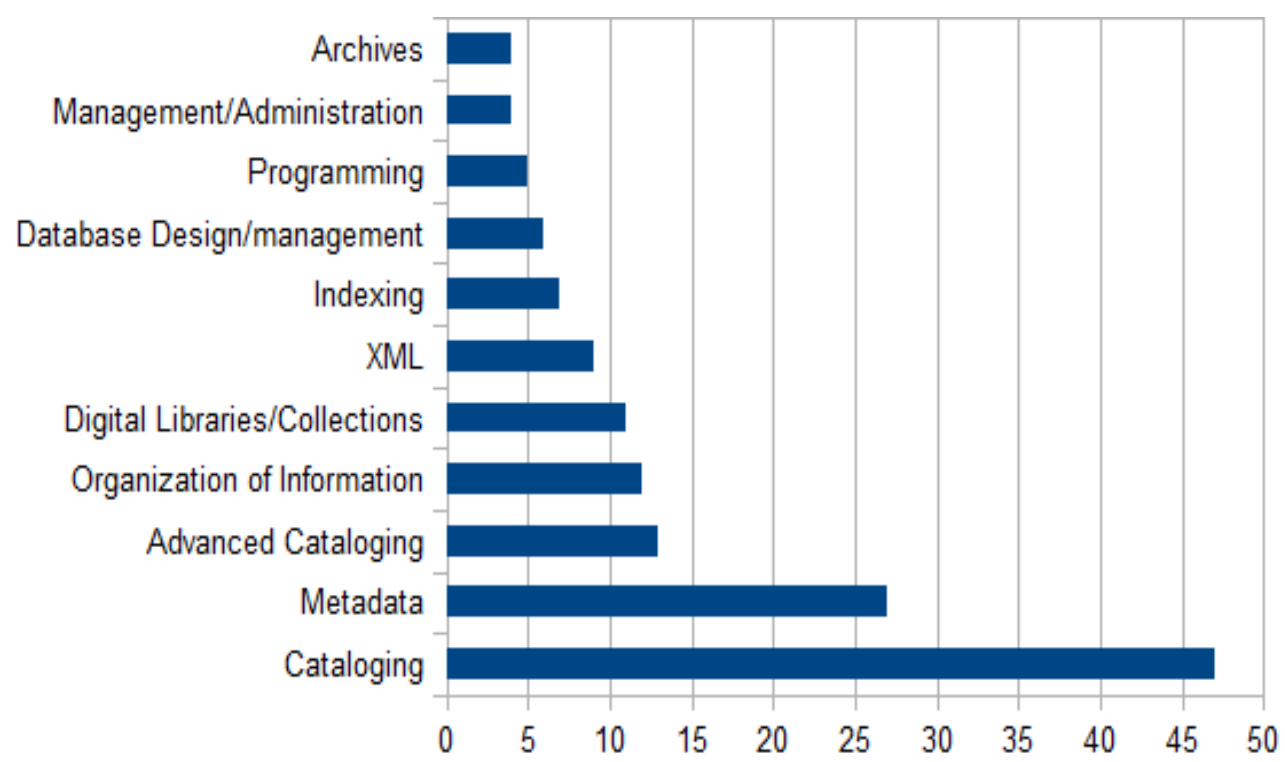

Table 4: Most useful courses taken by Metadata Librarians as reported by survey respondents. 
Taking the knowledge of their current job responsibilities into account, respondents were asked to name which courses they did not take in school, but that they most find themselves wishing they had taken. Again, many courses were listed only one or two times, but the subject areas shown in the graph in Table 5 indicate those subjects named most often by the 71 respondents who answered this question. By far the course most respondents felt they needed was some form of advanced metadata course or a metadata course covering emerging standards in the field, which appeared 20 times throughout the responses. Programming courses were also named frequently (13 times), with most respondents requesting general programming skills, while some named specific languages such as PHP or Python. Advanced cataloging courses were listed 10 times, after grouping together instances of "advanced cataloging", "image cataloging" and "serials cataloging." Also frequently mentioned was a course on XML/XSLT (7 times).

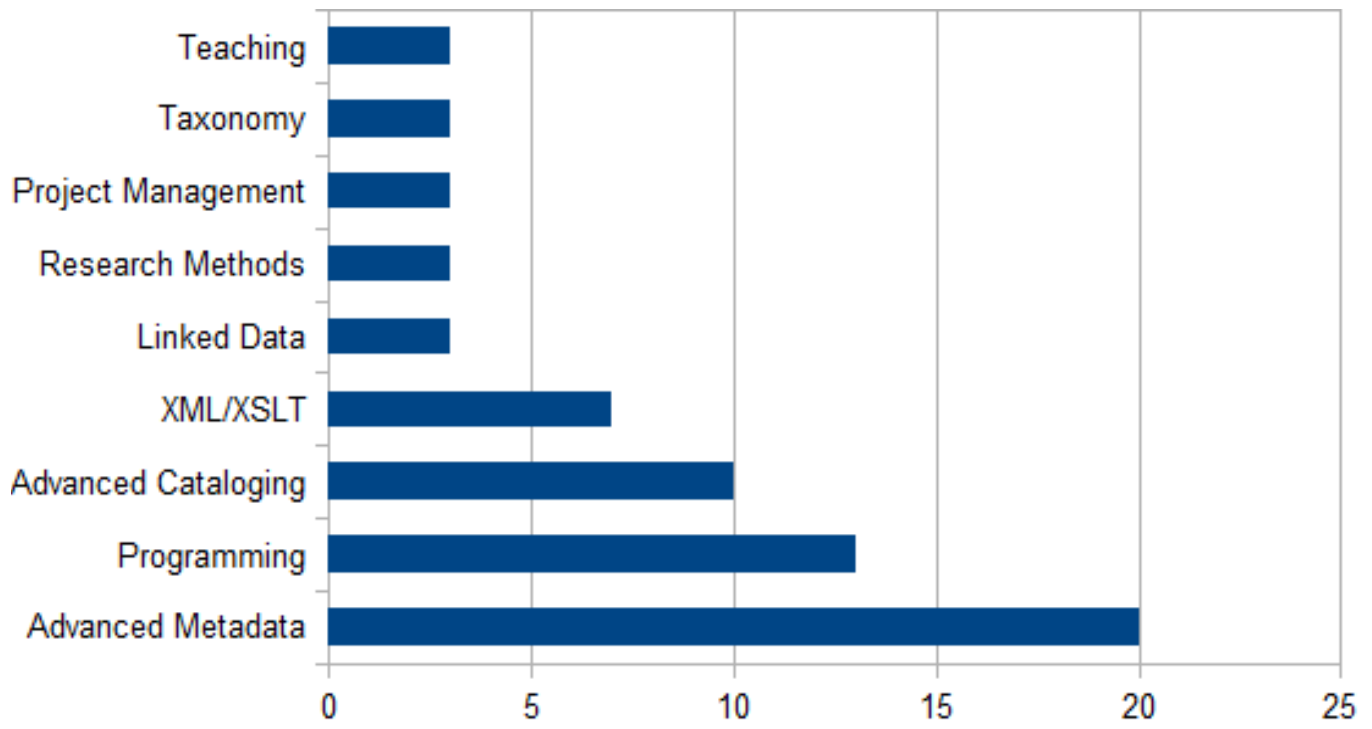

Table 5: Courses Metadata Librarians most wish they had taken in school as reported by survey respondents.

\section{DISCUSSION}

While the results of the survey represent only a small portion of those currently working in the metadata field, there were many reoccurring themes which appeared throughout the survey results. The variety of job titles of those working with metadata suggests that this is still an area of transition that does not yet represent its own specific field. A sizable percentage of respondents who are currently working with metadata have job titles that are related to cataloging or technical services. This may be partially due to the inclusion of traditional 
cataloging standards such as MARC and AACR2 in the definition of metadata. It could also be representative of the current need for librarians to perform multiple job duties regardless of title. The equally large number of respondents with job titles incorporating both cataloging and metadata also speaks to this trend in combining not only job duties, but titles as well. However, the largest category of job titles for those responding consisted of a metadata-specific title. This could reflect the increasing number of jobs appearing with metadata in the title, or it could also be due to the design of the survey. Since the survey was geared toward those working with metadata, those working solely with traditional cataloging standards may have been less likely to participate.

The percentage of their work that respondents devote specifically to metadata was also quite varied. While $16 \%$ of those responding devote $100 \%$ of their time to working with metadata, the remainder of respondents indicated that they spent less than $100 \%$ of their time on metadata (with $18 \%$ spending less than $50 \%$ of their time on metadata), reinforcing earlier studies that found that work in these areas of librarianship is often combined with other job duties (Glasser 2007, Chapman 2007, Park and Lu 2009).

The overwhelming majority of respondents answered that they work in an academic library, which could suggest that academic libraries are those most likely to employ librarians specifically for metadata work, or again, that those working in public libraries identify only as catalogers and therefore were less likely to respond to the survey.

The results to the question asking for the respondents' most commonly used metadata standards are also quite varied, with a large number of individual standards being named (including local or custom schemas). However, the most common non-MARC standard being used was Dublin Core, echoing earlier findings by Han and Hswe (2009), Park and Lu (2009), Hsieh-Yee (2003) and Veve and Feltner-Reichert (2010). For students looking for advice about which standards to take courses in or to gain experience in, these findings suggest that it would be the most beneficial to study traditional cataloging formats along with Dublin Core while in school, and wait to explore other schemas until they know which ones will be used by their employer.

The results of the survey also offer a glimpse into possible career trajectories and educational paths for LIS students hoping to enter this field. The majority of respondents came into the metadata field from a career in cataloging or technical services, suggesting students interested in metadata work may want to focus on these areas during school and while searching for an entry-level position. However, the wide variety of other positions from which metadata librarians entered the field also suggests that there are many positions that can give one the necessary experience working with metadata. Additionally, $14 \%$ of those responding were students or interns prior to taking their current position, 
suggesting that there are entry-level metadata positions to be found, or that onthe-job training is still a possibility in some organizations. With $80 \%$ of respondents answering that they had received additional metadata training after entering their current position, job-specific training through workshops, professional development courses or on-the-job training appears to be a common way of gaining and refining a current skill set. One respondent commented that "The best training and education I received has been on the job and through professional organizations such as ALCTS."

For those still in library school, the results of the survey offer numerous suggestions for course planning. Combining the results of the most helpful courses taken by respondents in library school with the courses respondents indicated they wished they had taken, the survey results indicate the most useful courses for current students hoping to enter the field of metadata are, in this order:

- cataloging

- metadata/advanced metadata topics

- advanced cataloging topics

- general programming

- XML

- organization of information

In spite of the focus on cataloging and metadata courses, however, respondents also stressed the importance of practical experience in addition to their education, echoing the findings from Dulock (2011) and Veitch et al (2013). One respondent wrote that "my cataloging and indexing courses gave me a solid foundation to be a cataloger. My work experience as a cataloger gave me a solid foundation to be a metadata librarian." Another wrote that even though he/she regretted not taking the school's metadata course, he/she was "not sure without real-life, on-the-job scenarios it would have been as beneficial." Practical experience was mentioned several times as being as or more important than courses taken in school. "Texts and classes are fine," one respondent wrote, "but the real challenge comes once you get out into the wilds."

Many respondents also stressed the importance of computer and programming courses, one even writing that such classes "should be compulsory in library school." Another respondent echoed the importance of learning some kind of computer programming, suggesting "coding! Working with code. Wrangling code," as important knowledge, while another suggested that "it is critical for metadata librarians today to know XSLT."

Along with general programming courses, participants also mentioned advanced metadata topics (or a course covering emerging metadata standards) most often as those not offered by their school, but important for building a foundation for working in the metadata field. This may be an area for further 
study as to the possible need for updating current library school curriculum to adequately cover the training necessary for work in this field.

\section{CONCLUSION}

The data in this study show that the field of metadata is one still in transition, where job titles and responsibilities are making the shift from traditional cataloging to non-MARC resource description. Even though occurrences of metadata job postings have risen as cataloging job postings have decreased, rather than being replaced, the cataloging field is integrating non-MARC metadata in response to libraries' increasing focus on the collection of electronic resources.

The data collected in this study show that there are a variety of job titles that can encompass metadata work, thus students searching for jobs in this field should consider additional keywords in their searches. And while a large variety of early-career positions can help to prepare employees for later work in the metadata field, a focus on traditional cataloging can help to lay a solid foundation for skills that will be needed by future metadata librarians.

Students should expect to continually supplement their education with professional development opportunities, such as workshops and conferences, even after becoming employed in the field. As library collections are likely to continue in the direction of electronic and Internet accessible resources, library schools will need to keep an eye on current technological trends and make the changes necessary to keep their curriculum as relevant as possible.

The findings from this study support the idea that a strong foundation in cataloging is the best preparation for a career in metadata, and students interested in this field should seek out courses on basic and advanced cataloging, metadata, and general programming, particularly XML. Students will also find great value in attaining hands-on experience in a cataloging or metadata practicum or internship, in addition to their classroom instruction. 
Appendix A

Metadata Librarian Survey

1. What is your job title? (required)

2. What percentage of your job directly involves working with metadata?

- $100 \%$

- More than $75 \%$

- More than $50 \%$

- Less than $50 \%$

3. In what type of library do you work?

- Public Library

- Academic Library

- Digital Library

- Special Library

- School Library

- Corporate/Business

- Other

4. What experience did you have with metadata before accepting your current position?

Professional development courses

口 Previous job(s)

Internship(s)

$\square$ School coursework

- Professional development (outside of library school)

$\square$ Other (please specify)

5. What kind of training did you receive in metadata after accepting your current position?

口 Professional development courses

$\square$ Workshops

Employer-sponsored training

On the job training

$\square$ No additional training

6. What was your job title in your most recent job prior to your current position? 
7. Did you take a metadata class in library school?

- Metadata specific course

- Course that covered metadata as a topic within a broader subject area

- Other (please specify)

8. What metadata standards do you commonly use in your current position?

9. What courses from library school do you find most helpful in your current position?

10. What courses do you wish had been offered that were not? 


\section{References}

Calhoun, K. (2007). Being a librarian: metadata and metadata specialists in the twenty-first century. Library Hi Tech, 25(2), 174-187. doi:10.1108/07378830710754947

Chapman, J. W. (2007). The roles of the metadata librarian in a research library. Library Resources and Technical Services, 51(4), 279-285. Retrieved from http://alcts.metapress.com/home/main.mpx

Dulock, M. (2011). New cataloger preparedness: Interviews with new professionals in academic libraries. Cataloging \& Classification Quarterly, 49(2), 65-96. doi:10.1080/01639374.2011.538910

Glasser, S. (2007). The changing face of cataloging positions at academic institutions: What skill set is needed, and how can students prepare? The Serials Librarian, 51(3/4), 39-49. doi:10.1300/J123v51n03_04

Hall-Ellis, S. D. (2006). Cataloging electronic resources and metadata: Employers' expectations as reflected in American Libraries and AutoCAT, 2000-2005. Journal of Education for Library and Information Science, 47(1), 38-51. Retrieved from http://a80.cci.fsu.edu/jelis/home/www/

Hall-Ellis, S. D. (2009). Descriptive impressions of entry-level cataloger positions as reflected in American Libraries, AutoCAT, and the Colorado State Library jobline, 2000-2003. Cataloging and Classification Quarterly, 40(2), 33-72. doi:10.1300/J104v40n02_05

Han, M. \& Hswe, P. (2009). The evolving role of the metadata librarian: competencies found in job descriptions. Library Resources and Technical Services, 54(3), 129-141. Retrieved from http://alcts.metapress.com/home/main.mpx

Hsieh-Yee, I. (2003). Cataloging and metadata education: A proposal for preparing cataloging professionals of the 21 st century. Report submitted to the ALCTS/ALISE Task Force in response to Action Item 5.1 of the Bibliographic Control of Web Resources: A Library of Congress Action Plan. Retrieved from http://www.loc.gov/catdir/bibcontrol/CatalogingandMetadataEducation.pdf 
NISO (2004). Understanding Metadata. Bethesda, MD: NISO Press. Retrieved from http://www.niso.org/publications/press/UnderstandingMetadata.pdf

Park, J., Tosaka, Y., Maszaros, S. \& Lu, C. (2010). From metadata creation to metadata quality control: Continuing education needs among cataloging and metadata professionals. Journal of Education for Library and Information Science, 51(3), 158-176. Retrieved from http://jelis.org/

Park, J. \& Lu, C. (2009). Metadata professionals: Roles and competencies as reflected in job announcements, 2003-2006. Cataloging and Classification Quarterly, 47(2), 145-160. doi:10.1080/01639370802575575

San Jose State University. (2013). Emerging career trends for information professionals: A snapshot of job titles in summer 2013. Retrieved from http://slisweb.sjsu.edu/downloads/emerging_trends_2012.pdf

Veitch, M., Greenberg, J., Keizer, C. \& Gunther, W. (2013). The UNC-Chapel Hill RDA boot camp: Preparing LIS students for emerging topics in cataloging and metadata. Cataloging \& Classification Quarterly, 51(4), 343-364. doi:10.1080/01639374.2012.736124

Veve, M. \& Feltner-Reichert, M. (2010). Integrating non-MARC metadata duties into the workflow of traditional catalogers: A survey of trends and perceptions among catalogers in four discussion lists. Technical Services Quarterly, 27(2), 194-213. doi:10.1080/07317130903585477 